Check for updates

Cite this: RSC Adv., 2018, 8, 30180

Received 2nd August 2018

Accepted 14th August 2018

DOI: $10.1039 / \mathrm{c} 8 \mathrm{ra06506c}$

rsc.li/rsc-advances

\title{
DABCO-catalyzed Knoevenagel condensation of aldehydes with ethyl cyanoacetate using hydroxy ionic liquid as a promoter
}

\author{
Dan Meng, ${ }^{a}$ Yongsheng Qiao, ${ }^{\mathrm{b}}$ Xin Wang, ${ }^{\mathrm{b}}$ Wei Wen ${ }^{\mathrm{b}}$ and Sanhu Zhao (D) *ab \\ $\mathrm{N}$-(2-Hydroxy-ethyl)-pyridinium chloride ([HyEtPy]Cl) was synthesized and explored as a novel promoter \\ for 1,4-diazabicyclo [2.2.2] octane (DABCO)-catalyzed Knoevenagel condensation reactions, which \\ showed better catalytic activity compared to other ionic liquid (IL) that had no hydroxyl group attached \\ to the IL scaffold. The effect of hydrogen bond formation between the hydroxyl group of [HyEtPy] Cl and \\ the carbonyl group of aldehyde played an important role in the Knoevenagel condensation reaction. In \\ the $[\mathrm{HyEtPy}] \mathrm{Cl}-\mathrm{H}_{2} \mathrm{O}-\mathrm{DABCO}$ composite system, Knoevenagel condensation reactions proceeded \\ smoothly and cleanly, and the corresponding Knoevenagel condensation products were obtained in \\ good to excellent yields in all cases examined. This protocol provides a versatile solvent-catalyst system, \\ which has notable advantages such as being eco-friendly, ease of work-up and convenient reuse of the \\ ionic liquid
}

\section{Introduction}

The Knoevenagel reaction, which was discovered by Knoevenagel in 1896, is a condensation reaction between activated methylene and carbonyl compounds. ${ }^{1}$ Owing to the fact that the $\alpha, \beta$-unsaturated carbonyl compounds produced by Knoevenagel reaction can further be used in the synthesis of fine chemicals, ${ }^{2}$ therapeutic drugs, ${ }^{3}$ natural products ${ }^{4}$ and functional polymers, ${ }^{5}$ research on this reaction has been a hot topic in organic synthesis. In recent years, a large number of catalytic systems were developed for this reaction and various new catalysts such as functionalized MOFs, ${ }^{6}$ functionalized fibers, ${ }^{7}$ simple molecular complexes, ${ }^{8} \mathrm{C}_{3} \mathrm{~N}_{4},{ }^{9}$ cage, ${ }^{10}$ copper powder, ${ }^{11}$ zeolites, $^{12}$ enzymes, ${ }^{13}$ polymers, ${ }^{14}$ bovine serum albumin, ${ }^{15}$ magnetic nanoparticles, ${ }^{16}$ graphene oxide ${ }^{17}$ and ammonium salts ${ }^{18}$ have been employed to catalyze this reaction, each affording variable yields of Knoevenagel condensation compounds. However, even for the most favorable systems, this reaction often suffers from expensive catalysts, laborious work-up procedures, long reaction times and use of organic solvents or toxic metals. Hence, there is an existing need for developing efficient and new methods based on green chemistry to improve the Knoevenagel condensation reaction.

${ }^{a}$ School Chemistry and Material Science, Shanxi Normal University, Linfen 041001, Shanxi, China.E-mail: sanhuzhao@163.com

${ }^{b}$ Department of Chemistry, Xinzhou Teachers University, Xinzhou 034000, Shanxi, China

$\uparrow$ Electronic supplementary information (ESI) available: NMR spectra of ionic salts and Knoevenagel products. See DOI: 10.1039/c8ra06506c
Currently, ionic liquids (ILs) are receiving great attention for their application as innovative solvents or additives in a variety of organic reactions. ${ }^{\mathbf{1 9}}$ In comparison to the common molecular solvents, the main characteristic of ILs is that they are completely composed of ions, which makes them ideal candidates to stabilize the intermediate of the addition reaction. ${ }^{20}$ For the Knoevenagel reaction, the base-catalyzed addition to a carbonyl group results from the nucleophilic attack of a strong nucleophile followed by protonation. Acid-catalyzed addition begins with protonation, followed by the attack of a weaker nucleophile. Protonation of the carbonyl oxygen atom plays an important role in the Knoevenagel reaction and hydrogen bond formation between the carbonyl group and the solvent or catalyst can accelerate this reaction. Based on the catalytic effect of hydrogen bond formation on the reaction and the stabilizing effect of ionic liquid on the reaction intermediate, we speculate that the use of an ionic liquid containing a hydroxyl group may exert an excellent accelerating effect. This deduction was considered to be reasonable because it was observed previously that hydroxyl groups or active hydrogens in an amine type catalyst did exert accelerating effects on some coupling reactions. $^{21}$

To meet our research interests, the ionic salt containing hydroxyl group was synthesized and applied in the DABCOcatalyzed Knoevenagel reaction (Scheme 1). To our delight, a significant beneficial effect of the ionic salt ([HyEtPy]Cl) over its non-hydroxyl counterpart was observed, and short reaction time and good to excellent yields of products were achieved. Herein, we would like to present the catalytic application of the hydroxyl pyridinium ionic liquid ([HyEtPy]Cl) in the Knoevenagel reaction. 


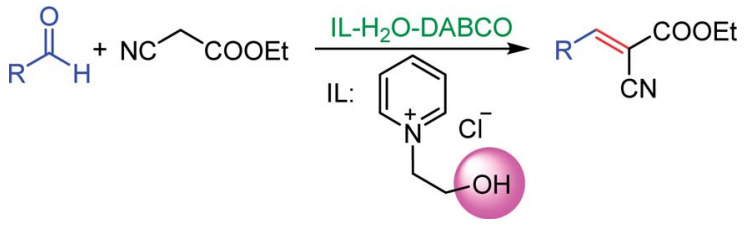

Scheme 1 Knoevenagel condensation reaction.

Table 1 Effects of the [HyEtPy]Cl- $\mathrm{H}_{2} \mathrm{O}-\mathrm{DABCO}$ composite system on Knoevenagel condensation ${ }^{a}$

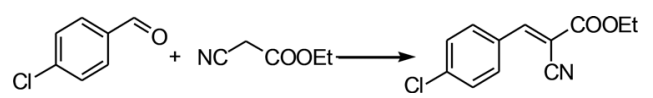

Entry Solvent-catalyst system Temperature Time (min) Yield $^{b}(\%)$

\begin{tabular}{lllll}
\hline 1 & $\mathrm{IL}-\mathrm{H}_{2} \mathrm{O}-\mathrm{HMTA}$ & $30{ }^{\circ} \mathrm{C}$ & 40 & 61 \\
2 & $\mathrm{IL}-\mathrm{H}_{2} \mathrm{O}-\mathrm{K}_{2} \mathrm{CO}_{3}$ & $30{ }^{\circ} \mathrm{C}$ & 40 & $\mathrm{ND}^{c}$ \\
3 & $\mathrm{IL}-\mathrm{H}_{2} \mathrm{O}-\mathrm{NaOH}$ & $30^{\circ} \mathrm{C}$ & 40 & 36 \\
4 & $\mathrm{IL}-\mathrm{H}_{2} \mathrm{O}-\mathrm{DABCO}$ & $30^{\circ} \mathrm{C}$ & 40 & 72 \\
5 & $\mathrm{IL}-\mathrm{H}_{2} \mathrm{O}-\mathrm{DABCO}$ & $40^{\circ} \mathrm{C}$ & 20 & 86 \\
6 & $\mathrm{IL}-\mathrm{H}_{2} \mathrm{O}-\mathrm{DABCO}$ & $50^{\circ} \mathrm{C}$ & 10 & 92 \\
7 & $\mathrm{IL}-\mathrm{H}_{2} \mathrm{O}-\mathrm{DABCO}$ & $60^{\circ} \mathrm{C}$ & 10 & 88 \\
$8^{d}$ & $\mathrm{IL}-\mathrm{H}_{2} \mathrm{O}-\mathrm{DABCO}$ & $50^{\circ} \mathrm{C}$ & 20 & 85 \\
$9^{e}$ & $\mathrm{IL}-\mathrm{H}_{2} \mathrm{O}-\mathrm{DABCO}$ & $50^{\circ} \mathrm{C}$ & 30 & 82 \\
$10^{f}$ & $\mathrm{IL}-\mathrm{H}_{2} \mathrm{O}-\mathrm{DABCO}$ & $50^{\circ} \mathrm{C}$ & $\mathbf{1 0}$ & $\mathbf{9 8}$ \\
$11^{g}$ & $\mathrm{IL}-\mathrm{H}_{2} \mathrm{O}-\mathrm{DABCO}$ & $50^{\circ} \mathrm{C}$ & 10 & 98 \\
12 & $\mathrm{IL}-\mathrm{H}_{2} \mathrm{O}$ & $50^{\circ} \mathrm{C}$ & 30 & $\mathrm{ND}$ \\
13 & $\mathrm{H}_{2} \mathrm{O}-\mathrm{DABCO}$ & $50^{\circ} \mathrm{C}$ & 30 & 46 \\
$14^{h}$ & $\mathrm{IL}-\mathrm{H}_{2} \mathrm{O}-\mathrm{DABCO}$ & $50^{\circ} \mathrm{C}$ & 20 & 82 \\
$15^{i}$ & $\mathrm{IL}-\mathrm{H}_{2} \mathrm{O}-\mathrm{DABCO}$ & $50^{\circ} \mathrm{C}$ & 20 & 84
\end{tabular}

${ }^{a}$ General reaction conditions: IL ([HyEtPy]Cl, $\left.3 \mathrm{~g}\right), \mathrm{H}_{2} \mathrm{O}(3 \mathrm{~mL}), \mathrm{DABCO}$ (10 mmol), 4-chlorobenzaldehyde $(10 \mathrm{mmol})$, ethyl cyanoacetate (12 mmol). ${ }^{b}$ Refers to work-up yield. ${ }^{c}$ Almost no product was detected. ${ }^{d} \mathrm{H}_{2} \mathrm{O}(6 \mathrm{~mL}) .{ }^{e} \mathrm{H}_{2} \mathrm{O}(1.5 \mathrm{~mL}) .{ }^{f}$ DABCO $(20 \mathrm{mmol}) .{ }^{g}$ DABCO (30 $\mathrm{mmol}) .{ }^{h} \mathrm{IL}$ is [PrPy]Cl (3 g). ${ }^{i} \mathrm{IL}$ is [BuPy]Cl (3 g).

More recently, amine-functionalized ionic liquids, ${ }^{22}$ protic ionic liquid $^{23}$ and $\mathrm{DABCO}^{24}$ or pyrrolidinium ${ }^{25}$ based ionic liquids were employed in the Knoevenagel reaction. The use of these ionic liquids effectively facilitated the Knoevenagel reaction. Some even achieved excellent results. However, the preparation of these ionic liquids often involved a consecutive quaternization-metathetic procedure, which made them expensive and their large scale industrial application difficult. ${ }^{26}$ Therefore, exploration of low cost, simple synthesis of ionic liquids and their use in organic synthesis will be of significance. At present, halogenated ionic salts can be easily prepared with high yields in large scale by one-step reaction of tertiary amines, tertiary phosphines or heterocyclic compounds containing nitrogen with halogenated hydrocarbons, but these ionic salts are mostly solid at room temperature, which hampers their direct use as solvents in organic reactions. ${ }^{27}$

Recently, as an environment friendly solvent, water has been used to promote organic reaction. ${ }^{28}$ To the best of our knowledge, it is generally easy to dissolve halogenated ionic salts in water to form homogeneous systems. Compared to pure ionic salts or water, the homogeneous system made up of water and ionic salts may have more excellent properties, which helps in the application of solid state halogenated ionic salts in organic reactions. Based on this point, the ionic salt containing hydroxyl group, 1-(2-hydroxy-ethyl)-pyridinium chloride ([HyEtPy]Cl), was conveniently synthesized by a one-step reaction according to literature procedures. ${ }^{29}$ Then, it was mixed with water, and the water-ionic liquid composite system formed was used in the Knoevenagel reaction of 4-chlorobenzaldehyde with ethyl cyanoacetate. Experimental results are summarized in Table 1.

As seen in Table 1, in the presence of water-ionic liquid composite system, moderate yield of $61 \%$ and good yield of $72 \%$ were obtained when the organic base hexamethylenetetramine (HMTA) or DABCO was used (Table 1, entries 1 and 4), and for the inorganic weak base $\mathrm{K}_{2} \mathrm{CO}_{3}$, almost no product was detected (Table 1, entry 2). Unfortunately, when the inorganic base $\mathrm{NaOH}$ was used, only $36 \%$ yield was obtained (Table 1, entry 3); it may be caused by Cannizzaro reaction of the aldehyde and hydrolysis of ethyl cyanoacetate in the presence of $\mathrm{NaOH}$. When the reaction temperature was changed (Table 1 , entries 4-7), the yield too changed, and the best yield of $92 \%$ was obtained at $50{ }^{\circ} \mathrm{C}$ (Table 1, entry 6). The reasons for this might be attributed to two factors: (i) high temperature enhanced the molecular reaction; and (ii) high temperature improved the solubility of the raw material and product and effectively avoided the inclusion of raw material with the product. However, when the temperature was higher than $50{ }^{\circ} \mathrm{C}$, the reaction color became darker and the yield decreased, which may be caused by enhanced side reaction. Further optimization of reaction conditions revealed that the amount of $\mathrm{H}_{2} \mathrm{O}$ also affected the reaction. When the amount of water was $50 \%$ (Table 1 , entry 6 ), excellent yield of $92 \%$ was obtained after $10 \mathrm{~min}$. When the amount of $\mathrm{H}_{2} \mathrm{O}$ was increased or decreased, the reaction time got significantly longer (Table 1, entries 8 and 9). After careful observation of the reaction, we noticed that the reaction system had insoluble raw material when the amount of water was increased to over $50 \%$ or decreased to less than $50 \%$. This suggested that the amount of water, more than or less than $50 \%$, can reduce the dissolution of raw material, which may affect the product yield. Further, increase in the amount of DABCO resulted in increase in the yield, and the highest reaction yield of $98 \%$ was obtained when $20 \mathrm{mmol}$ DABCO was added (Table 1, entry 10). However, the reaction time and yield remained same when the amount of catalyst was changed to $30 \mathrm{mmol}$ (Table 1, entry 11). To further confirm that the enhancement was from the [HyEtPy] $\mathrm{Cl}-\mathrm{H}_{2} \mathrm{O}-\mathrm{DABCO}$ composite system, the [HyEtPy]Cl- $\mathrm{H}_{2} \mathrm{O}$ and $\mathrm{H}_{2} \mathrm{O}-\mathrm{DABCO}$ composite system were used to test this reaction (Table 1, entries 12 and 13). In the [HyEtPy] $\mathrm{Cl}-\mathrm{H}_{2} \mathrm{O}$ composite system, the product was not detected after $30 \mathrm{~min}$, and in the $\mathrm{H}_{2} \mathrm{O}-\mathrm{DABCO}$ composite system, only $46 \%$ yield was obtained after $30 \mathrm{~min}$. Indeed, the ionic salt [HyEtPy]Cl played an important role in the solventcatalyst system. Comparing the ionic salt [HyEtPy]Cl with $N$ propylpyridinium chloride ([PrPy]Cl) (Table 1, entry 14) and $\mathrm{N}$ butylpyridinium chloride ([BuPy]Cl) (Table 1, entry 15), the hydroxyl ionic salt [HyEtPy]Cl provided slightly better results in terms of reaction yield and reaction time. Considering the 
Table 2 Knoevenagel condensation of aldehydes with ethyl cyanoacetate ${ }^{a}$

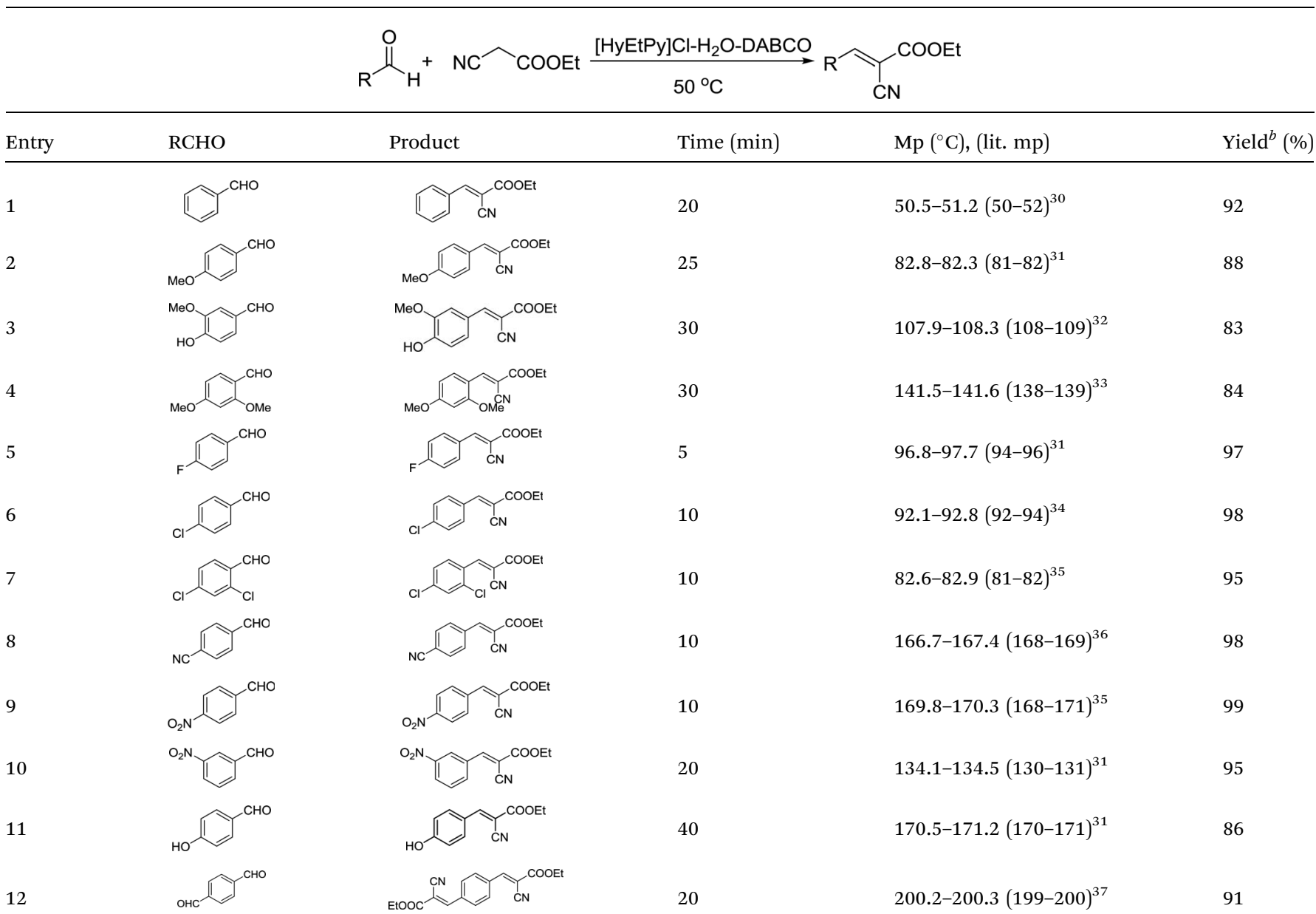

${ }^{a}$ General reaction conditions: [HyEtPy] $\mathrm{Cl}(3 \mathrm{~g}), \mathrm{H}_{2} \mathrm{O}(3 \mathrm{~mL})$, DABCO $(20 \mathrm{mmol})$, aldehyde $(10 \mathrm{mmol})$, ethyl cyanoacetate $(12 \mathrm{mmol}) .{ }^{b}$ Refers to workup yield.

Table 3 Reuse of the solvent system [HyEtPy] Cl- $\mathrm{H}_{2} \mathrm{O}^{a}$

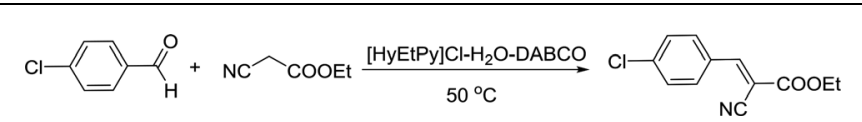

\begin{tabular}{lll}
\hline Cycle & Time $(\min )$ & Yield $(\%)$ \\
\hline 1 & 10 & 98 \\
2 & 10 & 97 \\
3 & 10 & 99 \\
4 & 10 & 98 \\
5 & 10 & 97 \\
6 & 10 & 97
\end{tabular}

${ }^{a}$ General reaction conditions: [HyEtPy]Cl $(3 \mathrm{~g}), \mathrm{H}_{2} \mathrm{O}(3 \mathrm{~mL})$, DABCO $(20$ $\mathrm{mmol})$, 4-chlorobenzaldehyde $(10 \mathrm{mmol})$ and ethyl cyanoacetate (12 $\mathrm{mmol})$.

similarity in the structures of the three pyridinium ionic salts, it was envisioned that the hydroxyl group in the ionic liquid [HyEtPy]Cl was responsible for its higher activity, and [HyEtPy]
$\mathrm{Cl}$ itself served as a protic additive to promote the Knoevenagel reaction in a manner similar to protic additives in conventional cases. Analysis of the results of Table 1 showed that the [HyEtPy] $\mathrm{Cl}-\mathrm{H}_{2} \mathrm{O}-\mathrm{DABCO}$ composite system was most suitable for the Knoevenagel reaction, and the best yield of $98 \%$ and the shortest reaction time of $10 \mathrm{~min}$ were obtained (Table 1, entry 10).

To further explore the catalytic efficacy of the [HyEtPy]Cl$\mathrm{H}_{2} \mathrm{O}$-DABCO composite system in Knoevenagel condensation, a number of aromatic aldehydes were chosen to condense with general active ethyl 2-cyanoacetate; the results are summarized in Table 2. The reaction was found to be applicable to aromatic aldehydes bearing various substituent groups such as nitro, chloro, cyano, methoxyl, hydroxyl, etc., and good to excellent yields (83-99\%) were obtained in short reaction times (5-40 min). Electron-rich salicylic aldehyde, which is usually an inert substrate, could provide a fairly good yield (86\%, entry 11) under the present conditions. The reactions of ethyl 2-cyanoacetate with electron-deficient 4-nitrobenzaldehyde, 4-fluorobenzaldehyde and 4-cyanobenzaldehyde provided excellent yields of 99\% (entry 9), 97\% (entry 5) and 98\% (entry 8), 


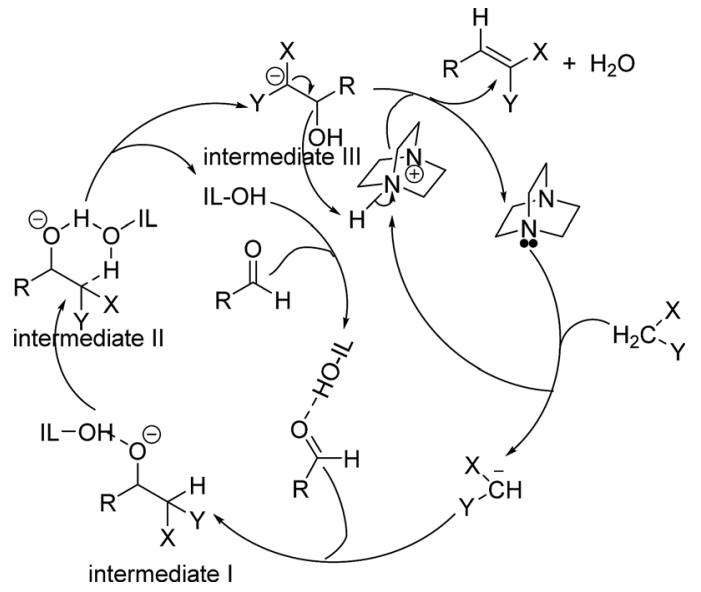

Scheme 2 Possible mechanism of Knoevenagel condensation in the [HyEtPy]Cl- $\mathrm{H}_{2} \mathrm{O}-\mathrm{DABCO}$ composite system.

respectively. Interestingly, when terephthalaldehyde was used as substrate, two aldehyde groups reacted with ethyl 2-cyanoacetate, and excellent yield of $91 \%$ of dual Knoevenagel adduct was obtained (entry 12). Generally, aromatic aldehydes bearing electron-withdrawing groups reacted more easily than those containing electron-donating groups.

To evaluate the possibility of recycling the composite system ([HyEtPy]Cl- $\left.\mathrm{H}_{2} \mathrm{O}\right)$ used for the Knoevenagel reaction, ethyl cyanoacetate $(12 \mathrm{mmol})$ and DABCO $(20 \mathrm{mmol})$ were added to a solution of 4-chlorobenzaldehyde $(10 \mathrm{mmol})$ in the composite system [HyEtPy]Cl- $\mathrm{H}_{2} \mathrm{O}\left(3 \mathrm{~mL} \mathrm{H}_{2} \mathrm{O}\right.$ and $3 \mathrm{~g}$ [HyEtPy]Cl). The reaction mixture was stirred at $50{ }^{\circ} \mathrm{C}$. The reaction progress was monitored by thin layer chromatography (TLC) until the aldehyde was consumed. The reaction mixture was extracted with diethyl ether $(2 \times 20 \mathrm{~mL})$. The combined diethyl ether mixture was washed with saturated brine $(2 \times 20 \mathrm{~mL})$ and dried over anhydrous $\mathrm{Na}_{2} \mathrm{SO}_{4}$, and then the solvent was removed on a rotary vacuum evaporator and almost pure product was obtained. Then, 4-chlorobenzaldehyde, ethyl cyanoacetate and DABCO were added to the recycled composite system [HyEtPy] $\mathrm{Cl}-\mathrm{H}_{2} \mathrm{O}$ to repeat the reaction. The recovered composite system was used at least six times without notable reduction in the reaction yields (Table 3, entries 1-6).

A plausible mechanism for the formation of Knoevenagel adduct in the presence of [HyEtPy]Cl- $\mathrm{H}_{2} \mathrm{O}-\mathrm{DABCO}$ composite system is depicted in Scheme 2. First, the carbonyl group of the aldehyde was protonated by $\mathrm{O}-\mathrm{H}$ of [HyEtPy] Cl (IL-OH), and the hydrogen atom of the active methylene interacted with the lone pair of electrons on the basic $\mathrm{N}$ centre (DABCO). The basic $\mathrm{N}$ abstracted a hydrogen from the active methylene and formed a carbanion, which attacked the carbonyl carbon and formed intermediate I. Then, the hydrogen atom of the active methylene interacted with the basic $\mathrm{O}$ centre in the IL-OH through a six-member ring (intermediate II), and intermediate III was formed. In intermediate III, the acidic $\mathrm{N}-\mathrm{H}$ of the quaternary ammonium interacted with the lone pair electrons on the oxygen atom of the hydroxyl group, and subsequent elimination of water resulted in the formation of the olefin. In this process,
[HyEtPy]Cl (IL-OH) not only activated the carbonyl group of aldehyde and stabilized the reaction intermediates, but also accelerated the Knoevenagel reaction by allowing protontransfer to occur via a six-member ring in which IL-OH acted as a shuttle to transfer the proton from the C-position to the alkoxide of intermediate II.

\section{Conclusions}

A recyclable protic-ionic-liquid solvent-catalyst system, [HyEtPy]Cl- $\mathrm{H}_{2} \mathrm{O}-\mathrm{DABCO}$, was developed and used in the Knoevenagel condensation reaction of aromatic aldehydes with ethyl 2-cyanoacetate. The composite system ([HyEtPy]Cl- $\mathrm{H}_{2} \mathrm{O}-$ DABCO) was readily prepared by simply mixing solid [HyEtPy]Cl with water and DABCO at a given ratio. At $50{ }^{\circ} \mathrm{C}$, the Knoevenagel condensation promoted by the composite system proceeded well, and the solvent-catalyst system $[\mathrm{HyEtPy}] \mathrm{Cl}-\mathrm{H}_{2} \mathrm{O}$ was recycled at least 6 times, showing no significant loss of activity. This protocol has notable advantages such as being ecofriendly, having low disposal costs, ease of work-up and convenient reuse of ionic liquid, which makes the present protocol practical for preparing multifunctional Knoevenagel condensation products.

\section{Experimental section}

${ }^{1} \mathrm{H}-\mathrm{NMR}$ (600, 500 or $400 \mathrm{MHz}$ ) and ${ }^{13} \mathrm{C}-\mathrm{NMR}$ (151, 126 or 101 $\mathrm{MHz}$ ) spectra were recorded at ambient temperatures using DMSO- $d_{6}$ or $\mathrm{CDCl}_{3}$ as solvent. ${ }^{1} \mathrm{H}$ - and ${ }^{13} \mathrm{C}-\mathrm{NMR}$ chemical shifts were reported in ppm relative to internal $\mathrm{Me}_{4} \mathrm{Si}$. IR spectra were determined on an FTIR-8400 infrared spectrometer by dispersing samples in $\mathrm{KBr}$ disks. Melting points were measured on a WRS-1B digital melting point meter and are uncorrected. All chemical reagents were obtained from commercial suppliers and used without further purification.

\section{Preparation and characterization of the ionic salts}

1-(2-Hydroxy-ethyl)-pyridinium chloride([HyEtPy]Cl). The ionic salt [HyEtPy]Cl was prepared according to a literature procedure $^{38}$ with the following modifications: excess 2-chloroethanol (51 mL, $0.76 \mathrm{~mol})$ and pyridine $(53 \mathrm{~mL}, 0.63 \mathrm{~mol})$ were transferred to a $250 \mathrm{~mL}$ round bottom flask, which was fitted with reflux condenser and nitrogen protecting facilities, and the reaction mixture was gently stirred at $70{ }^{\circ} \mathrm{C}$ for $24 \mathrm{~h}$ in the dark; the crude product [HyEtPy]Cl was formed. Then, the crude product was purified by recrystallization with $5 \mathrm{~mL}$ acetonitrile and $25 \mathrm{~mL}$ ethyl acetate solvent, and the residual solvent was removed in vacuum to give the product [HyEtPy] Cl (95 g, 94\%) as white crystals. Mp $124{ }^{\circ} \mathrm{C} ;{ }^{1} \mathrm{H}-\mathrm{NMR}$ (600 MHz, DMSO- $d_{6}$ ) $\delta 9.12\left(\mathrm{~d}, J=5.3 \mathrm{~Hz}, 2 \mathrm{H}, \mathrm{CH}=\mathrm{N}^{+}\right), 8.63(\mathrm{t}, J=7.8 \mathrm{~Hz}, 1 \mathrm{H}, \mathrm{CH}=)$, 8.26-8.10 (m, $2 \mathrm{H}, \mathrm{CH}=), 5.61(\mathrm{~d}, J=4.9 \mathrm{~Hz}, 1 \mathrm{H}, \mathrm{OH}), 4.79-4.62$ $\left(\mathrm{m}, 2 \mathrm{H}, \mathrm{N}-\mathrm{CH}_{2}\right), 3.85$ (dd, $\left.J=10.1,5.2 \mathrm{~Hz}, 2 \mathrm{H}, \mathrm{CH}_{2} \mathrm{O}\right) ;{ }^{13} \mathrm{C}-\mathrm{NMR}$ $\left(151 \mathrm{MHz}, \mathrm{DMSO}-d_{6}\right) \delta 148.86,148.61,131.01,66.28,63.28$.

1-Butylpyridinium chloride ([BuPy]Cl). The same procedure as that described above for [HyEtPy]Cl was followed except for the use of 1-chlorobutane $(99 \mathrm{~mL}, 0.95 \mathrm{~mol})$ instead of 2- 
chloroethanol. The product [BuPy]Cl (99 g, 92\%) was obtained as white crystalline solid. Mp $87{ }^{\circ} \mathrm{C}$ (lit., $\left.{ }^{38} 86{ }^{\circ} \mathrm{C}\right) ;{ }^{1} \mathrm{H}-\mathrm{NMR}(500$ MHz, DMSO- $\left.d_{6}\right) \delta 0.89\left(\mathrm{~s}, 3 \mathrm{H}, \mathrm{CH}_{3}\right), 1.28\left(\mathrm{~s}, 2 \mathrm{H}, \mathrm{CH}_{2}\right), 1.89(\mathrm{~s}$, $\left.2 \mathrm{H}, \mathrm{CH}_{2}\right), 4.72\left(\mathrm{t}, J=10.0 \mathrm{~Hz}, 2 \mathrm{H}, \mathrm{N}-\mathrm{CH}_{2}\right), 8.20(\mathrm{~s}, 2 \mathrm{H}, \mathrm{CH}=)$, $8.66(\mathrm{~s}, 1 \mathrm{H}, \mathrm{CH}=), 9.35\left(\mathrm{~s}, 2 \mathrm{H}, \mathrm{CH}=\mathrm{N}^{+}\right) ;{ }^{13} \mathrm{C}-\mathrm{NMR}(125 \mathrm{MHz}$, DMSO- $\left.d_{6}\right) \delta 145.66,144.77,128.04,60.19,32.60,18.95,13.45$.

\section{General procedure for Knoevenagel condensation reaction}

$20 \mathrm{mmol}$ DABCO was added to a stirred mixture of $10 \mathrm{mmol}$ aldehyde and $12 \mathrm{mmol}$ ethyl cyanoacetate in $6.0 \mathrm{~g}$ [HyEtPy]Cl$\mathrm{H}_{2} \mathrm{O}\left(3 \mathrm{~mL} \mathrm{H}_{2} \mathrm{O}\right.$ and $3 \mathrm{~g}$ [HyEtPy]Cl) at room temperature. The reaction progress was monitored by thin layer chromatography (TLC) until the aldehyde was consumed. Then, the reaction mixture was diluted with water $(30 \mathrm{~mL})$ and extracted with $\mathrm{Et}_{2} \mathrm{O}$ $(2 \times 20 \mathrm{~mL})$; the organic phase was washed with brine $(2 \times 20$ $\mathrm{mL}$ ), dried over anhydrous $\mathrm{Na}_{2} \mathrm{SO}_{4}$, and the solvent removed on a rotary vacuum evaporator to yield the almost pure product. Further purification could be achieved by recrystallization from ethanol. The products were characterized by melting point determination, IR and NMR spectroscopy; the spectral data of all products (Table 2) are listed as follows.

Ethyl-2-cyano-3-phenylacrylate (entry 1). White crystalline solid; ${ }^{1} \mathrm{H}-\mathrm{NMR}\left(400 \mathrm{MHz}, \mathrm{CDCl}_{3}\right) \delta 8.25(\mathrm{~s}, 1 \mathrm{H}, \mathrm{CH}=), 7.99(\mathrm{~d}, J$ $=7.2 \mathrm{~Hz}, 2 \mathrm{H}, \mathrm{ArH}), 7.60-7.39(\mathrm{~m}, 3 \mathrm{H}, \mathrm{ArH}), 4.39(\mathrm{q}, J=7.1 \mathrm{~Hz}$, $\left.2 \mathrm{H}, \mathrm{CH}_{2}\right), 1.40$ (t, $\left.J=7.1 \mathrm{~Hz}, 3 \mathrm{H}, \mathrm{CH}_{3}\right)$. FT-IR $\left(\mathrm{KBr}, \mathrm{cm}^{-1}\right): 3035$ $(\mathrm{C}=\mathrm{CH}), 2980\left(-\mathrm{CH}_{2} \mathrm{CH}_{3}\right), 2223(-\mathrm{CN}), 1729(\mathrm{C}=\mathrm{O}), 1608(\mathrm{C}=$ C), 1263 (C-O), 768 (ArH), 680 (ArH).

Ethyl-2-cyano-3-(4-methoxy-phenyl)acrylate (entry 2). Pale yellow crystalline solid; ${ }^{1} \mathrm{H}-\mathrm{NMR}\left(400 \mathrm{MHz}, \mathrm{CDCl}_{3}\right) \delta 8.17(\mathrm{~s}, 1 \mathrm{H}$, $\mathrm{CH}=), 8.01(\mathrm{~d}, J=8.8 \mathrm{~Hz}, 2 \mathrm{H}, \mathrm{ArH}), 7.00(\mathrm{~d}, J=8.9 \mathrm{~Hz}, 2 \mathrm{H}$, $\operatorname{ArH}), 4.37$ (q, $\left.J=7.1 \mathrm{~Hz}, 2 \mathrm{H}, \mathrm{CH}_{2}\right), 3.9\left(\mathrm{~s}, 3 \mathrm{H}, \mathrm{OCH}_{3}\right), 1.40(\mathrm{t}, J=$ $\left.7.1 \mathrm{~Hz}, 3 \mathrm{H}, \mathrm{CH}_{3}\right)$. FT-IR $\left(\mathrm{KBr}, \mathrm{cm}^{-1}\right): 3024(\mathrm{C}=\mathrm{CH}), 2992$ $\left(-\mathrm{CH}_{2} \mathrm{CH}_{3}\right), 2216(-\mathrm{CN}), 1717(\mathrm{C}=\mathrm{O}), 1585(\mathrm{C}=\mathrm{C}), 1262(\mathrm{C}-\mathrm{O})$, 838 (ArH).

Ethyl-2-cyano-3-(4-hydroxy-3-methoxyphenyl)acrylate

(entry3). Pale yellow crystalline solid; ${ }^{1} \mathrm{H}-\mathrm{NMR}(400 \mathrm{MHz}$, $\left.\mathrm{CDCl}_{3}\right) \delta 8.14(\mathrm{~s}, 1 \mathrm{H}, \mathrm{CH}=), 7.85(\mathrm{~s}, 1 \mathrm{H}, \mathrm{ArH}), 7.40(\mathrm{~d}, J=6.3 \mathrm{~Hz}$, $1 \mathrm{H}, \operatorname{ArH}), 7.00(\mathrm{~d}, J=6.3 \mathrm{~Hz}, 1 \mathrm{H}, \operatorname{ArH}), 4.38(\mathrm{q}, J=7.2 \mathrm{~Hz}, 2 \mathrm{H}$, $\mathrm{CH}_{2}$ ), $3.98\left(\mathrm{~s}, 3 \mathrm{H}, \mathrm{OCH}_{3}\right), 1.34\left(\mathrm{t}, J=7.2 \mathrm{~Hz}, 3 \mathrm{H}, \mathrm{CH}_{3}\right)$. FT-IR $\left(\mathrm{KBr}, \mathrm{cm}^{-1}\right): 3024(\mathrm{C}=\mathrm{CH}), 2992\left(-\mathrm{CH}_{2} \mathrm{CH}_{3}\right), 2216(-\mathrm{CN}), 1717$ $(\mathrm{C}=\mathrm{O}), 1585(\mathrm{C}=\mathrm{C}), 1262(\mathrm{C}-\mathrm{O}), 835(\mathrm{ArH})$.

Ethyl-2-cyano-3-(2,4-dimethoxyphenyl)acrylate (entry 4). Yellow crystalline solid; ${ }^{1} \mathrm{H}-\mathrm{NMR}\left(400 \mathrm{MHz}, \mathrm{CDCl}_{3}\right) \delta 8.67(\mathrm{~s}, 1 \mathrm{H}$, $\mathrm{CH}=), 8.38(\mathrm{~d}, J=8.9 \mathrm{~Hz}, 1 \mathrm{H}, \operatorname{ArH}), 6.58(\mathrm{~d}, J=11.2 \mathrm{~Hz}, 1 \mathrm{H}$, $\operatorname{ArH}), 6.58$ (d, $J=11.2 \mathrm{~Hz}, 1 \mathrm{H}, \mathrm{ArH}), 4.35\left(\mathrm{q}, J=7.1 \mathrm{~Hz}, 2 \mathrm{H}, \mathrm{CH}_{2}\right)$, $3.89\left(\mathrm{~s}, 6 \mathrm{H}, \mathrm{OCH}_{3}\right), 1.38\left(\mathrm{t}, J=7.1 \mathrm{~Hz}, 3 \mathrm{H}, \mathrm{CH}_{3}\right)$. FT-IR $\left(\mathrm{KBr}, \mathrm{cm}^{-1}\right): 3024(\mathrm{ArH}), 2983\left(-\mathrm{CH}_{2} \mathrm{CH}_{3}\right), 2215(-\mathrm{CN}), 1713$ $(\mathrm{C}=\mathrm{O}), 1610(\mathrm{C}=\mathrm{C}), 1249$ (C-O), $836(\mathrm{ArH})$.

Ethyl-2-cyano-3-(4-fluorophenyl)acrylate (entry 5). White solid; ${ }^{1} \mathrm{H}-\mathrm{NMR}\left(400 \mathrm{MHz}, \mathrm{CDCl}_{3}\right) \delta 8.22(\mathrm{~s}, 1 \mathrm{H}, \mathrm{CH}=), 8.04(\mathrm{~d}, J$ $=8.6 \mathrm{~Hz}, 2 \mathrm{H}, \operatorname{ArH}), 7.20(\mathrm{t}, J=8.6 \mathrm{~Hz}, 2 \mathrm{H}, \operatorname{ArH}), 4.39(\mathrm{q}, J=$ $\left.7.1 \mathrm{~Hz}, 2 \mathrm{H}, \mathrm{CH}_{2}\right), 1.41\left(\mathrm{t}, J=7.1 \mathrm{~Hz}, 3 \mathrm{H}, \mathrm{CH}_{3}\right)$. FT-IR $\left(\mathrm{KBr}, \mathrm{cm}^{-1}\right)$ : $3025(\mathrm{C}=\mathrm{CH}), 2990\left(-\mathrm{CH}_{2} \mathrm{CH}_{3}\right), 2219(-\mathrm{CN}), 1717(\mathrm{C}=\mathrm{O}), 1585$ $(\mathrm{C}=\mathrm{C}), 1270$ (C-O), 896 (ArH).

Ethyl-3-(4-chlorophenyl)-2-cyanoacrylate (entry 6). White crystalline solid; ${ }^{1} \mathrm{H}-\mathrm{NMR}\left(400 \mathrm{MHz}, \mathrm{CDCl}_{3}\right) \delta 8.18(\mathrm{~s}, 1 \mathrm{H}$,
$\mathrm{CH}=), 7.92(\mathrm{~d}, J=8.4 \mathrm{~Hz}, 2 \mathrm{H}, \mathrm{ArH}), 7.46(\mathrm{~d}, J=8.4 \mathrm{~Hz}, 2 \mathrm{H}$, $\operatorname{ArH}), 4.38$ (q, $\left.J=7.1 \mathrm{~Hz}, 2 \mathrm{H}, \mathrm{CH}_{2}\right), 1.39$ (t, $J=7.1 \mathrm{~Hz}, 3 \mathrm{H}, \mathrm{CH}_{3}$ ). ${ }^{13} \mathrm{C}-\mathrm{NMR}\left(101 \mathrm{MHz}, \mathrm{CDCl}_{3}\right) \delta 162.0,153.3,139.5,132.2,129.9$, 129.6, 115.2, 103.5, 62.8, 14.1. FT-IR ( $\left.\mathrm{KBr}, \mathrm{cm}^{-1}\right): 3035$ (ArH), $2989\left(-\mathrm{CH}_{2} \mathrm{CH}_{3}\right), 2954\left(-\mathrm{CH}_{2} \mathrm{CH}_{3}\right), 2223(-\mathrm{CN}), 1724(\mathrm{C}=\mathrm{O})$, $1652(\mathrm{C}=\mathrm{C}), 1612(\mathrm{C}=\mathrm{C}), 1200(\mathrm{C}-\mathrm{O}), 831(\mathrm{ArH})$.

Ethyl-3-(2,4-dichlorophenyl)-2-cyanoacrylate (entry 7). White solid; ${ }^{1} \mathrm{H}-\mathrm{NMR}\left(400 \mathrm{MHz}, \mathrm{CDCl}_{3}\right) \delta 8.63(\mathrm{~s}, 1 \mathrm{H}, \mathrm{CH}=), 8.22(\mathrm{~d}, J$ $=8.6 \mathrm{~Hz}, 1 \mathrm{H}, \mathrm{ArH}), 7.55(\mathrm{~s}, 1 \mathrm{H}, \operatorname{ArH}), 7.42(\mathrm{~d}, J=10.3 \mathrm{~Hz}, 1 \mathrm{H}$, $\operatorname{ArH}), 4.43$ (q, $\left.J=7.1 \mathrm{~Hz}, 2 \mathrm{H}, \mathrm{CH}_{2}\right), 1.43\left(\mathrm{t}, J=7.1 \mathrm{~Hz}, 3 \mathrm{H}, \mathrm{CH}_{3}\right)$. FT-IR ( $\left.\mathrm{KBr}, \mathrm{cm}^{-1}\right): 3038(\mathrm{ArH}), 2990\left(-\mathrm{CH}_{2} \mathrm{CH}_{3}\right), 2223(-\mathrm{CN})$, $1725(\mathrm{C}=\mathrm{O}), 1652(\mathrm{C}=\mathrm{C}), 1580(\mathrm{C}=\mathrm{C}), 1257(\mathrm{C}-\mathrm{O}), 865(\mathrm{ArH})$.

Ethyl-2-cyano-3-(4-cyanophenyl)acrylate (entry 8). White crystalline solid; ${ }^{1} \mathrm{H}-\mathrm{NMR}\left(500 \mathrm{MHz}, \mathrm{CDCl}_{3}\right) \delta 8.25(\mathrm{~s}, 1 \mathrm{H}$, $\mathrm{CH}=), 8.07(\mathrm{~d}, J=8.4 \mathrm{~Hz}, 2 \mathrm{H}, \operatorname{ArH}), 7.80(\mathrm{~d}, J=8.3 \mathrm{~Hz}, 2 \mathrm{H}$, $\mathrm{ArH}), 4.42$ (q, $\left.J=6.8 \mathrm{~Hz}, 2 \mathrm{H}, \mathrm{CH}_{2}\right), 1.42\left(\mathrm{t}, J=7.5 \mathrm{~Hz}, 3 \mathrm{H}, \mathrm{CH}_{3}\right)$. FT-IR (KBr, cm $\left.{ }^{-1}\right): 3032$ (ArH), $2994 \quad\left(-\mathrm{CH}_{2} \mathrm{CH}_{3}\right), 2943$ $\left(-\mathrm{CH}_{2} \mathrm{CH}_{3}\right), 2226(-\mathrm{CN}), 1714(\mathrm{C}=\mathrm{O}), 1620(\mathrm{C}=\mathrm{C}), 1260(\mathrm{C}-\mathrm{O})$, 840 ( $\mathrm{ArH})$.

Ethyl-3-(4-nitrophenyl)-2-cyanoacrylate (entry 9). Yellow crystalline solid; ${ }^{1} \mathrm{H}-\mathrm{NMR}\left(400 \mathrm{MHz}, \mathrm{CDCl}_{3}\right) \delta 8.37(\mathrm{~d}, J=8.8 \mathrm{~Hz}$, $2 \mathrm{H}, \mathrm{ArH}), 8.33(\mathrm{~s}, 1 \mathrm{H}, \mathrm{CH}=), 8.16(\mathrm{~d}, J=8.8 \mathrm{~Hz}, 2 \mathrm{H}, \mathrm{ArH}), 4.45$ (q, $\left.J=7.1 \mathrm{~Hz}, 2 \mathrm{H}, \mathrm{CH}_{2}\right), 1.44\left(\mathrm{t}, J=7.1 \mathrm{~Hz}, 3 \mathrm{H}, \mathrm{CH}_{3}\right)$. FT-IR $\left(\mathrm{KBr}, \mathrm{cm}^{-1}\right): 3040(\mathrm{ArH}), 2990\left(-\mathrm{CH}_{2} \mathrm{CH}_{3}\right), 2240(-\mathrm{CN}), 1721$ $(\mathrm{C}=\mathrm{O}), 1617(\mathrm{C}=\mathrm{C}), 1202(\mathrm{C}-\mathrm{O}), 861(\mathrm{ArH})$.

Ethyl-3-(3-nitrophenyl)-2-cyanoacrylate (entry 10). Pale yellow solid; ${ }^{1} \mathrm{H}-\mathrm{NMR}\left(400 \mathrm{MHz}, \mathrm{CDCl}_{3}\right) \delta 8.72$ (s, $\left.1 \mathrm{H}, \mathrm{ArH}\right), 8.42$ $(\mathrm{d}, J=6.6 \mathrm{~Hz}, 2 \mathrm{H}, \mathrm{ArH}), 8.33(\mathrm{~s}, 1 \mathrm{H}, \mathrm{C}=\mathrm{CH}), 7.76(\mathrm{~d}, J=8.1 \mathrm{~Hz}$, $1 \mathrm{H}, \mathrm{ArH}), 4.43\left(\mathrm{q}, J=7.1 \mathrm{~Hz}, 2 \mathrm{H}, \mathrm{CH}_{2}\right), 1.42(\mathrm{t}, J=7.1 \mathrm{~Hz}, 3 \mathrm{H}$, $\left.\mathrm{CH}_{3}\right)$. FT-IR ( $\left.\mathrm{KBr}, \mathrm{cm}^{-1}\right): 3035(\mathrm{ArH}), 2998\left(-\mathrm{CH}_{2} \mathrm{CH}_{3}\right), 2226$ $(-\mathrm{CN}), 1727(\mathrm{C}=\mathrm{O}), 1627(\mathrm{C}=\mathrm{C}), 1272(\mathrm{C}-\mathrm{O}), 764(\mathrm{ArH})$.

Ethyl-2-cyano-3-(4-hydroxyphenyl)acrylate (entry 11). Yellow solid; ${ }^{1} \mathrm{H}-\mathrm{NMR}\left(500 \mathrm{MHz}, \mathrm{CDCl}_{3}\right) \delta 8.22(\mathrm{~s}, 1 \mathrm{H}, \mathrm{CH}=), 7.98(\mathrm{~d}, J$ $=8.2 \mathrm{~Hz}, 2 \mathrm{H}, \operatorname{ArH}), 7.01(\mathrm{~d}, J=8.2 \mathrm{~Hz}, 2 \mathrm{H}, \operatorname{ArH}), 4.41(\mathrm{q}, J=$ $\left.6.8 \mathrm{~Hz}, 2 \mathrm{H}, \mathrm{CH}_{2}\right), 3.52(\mathrm{~s}, 1 \mathrm{H}, \mathrm{OH}), 1.43\left(\mathrm{t}, J=6.8 \mathrm{~Hz}, 3 \mathrm{H}, \mathrm{CH}_{3}\right)$. FT-IR ( $\left.\mathrm{KBr}, \mathrm{cm}^{-1}\right)$ : $3410(-\mathrm{OH}), 3032(\mathrm{ArH}), 2994\left(-\mathrm{CH}_{2} \mathrm{CH}_{3}\right)$, $2226(-\mathrm{CN}), 1712(\mathrm{C}=\mathrm{O}), 1618(\mathrm{C}=\mathrm{C}), 1258(\mathrm{C}-\mathrm{O}), 835(\mathrm{ArH})$.

Diethyl-3,3'-(1,4-phenylene)bis(2-cyanoacrylate) (entry 12). White crystalline solid; ${ }^{1} \mathrm{H}-\mathrm{NMR}\left(400 \mathrm{MHz}, \mathrm{CDCl}_{3}\right) \delta 8.27(\mathrm{~s}, 2 \mathrm{H}$, $\mathrm{CH}=), 8.11(\mathrm{~s}, 4 \mathrm{H}, \mathrm{ArH}), 4.42\left(\mathrm{q}, J=7.1 \mathrm{~Hz}, 4 \mathrm{H}, \mathrm{CH}_{2}\right), 1.42(\mathrm{t}, J=$ $\left.7.1 \mathrm{~Hz}, 6 \mathrm{H}, \mathrm{CH}_{3}\right)$. FT-IR $\left(\mathrm{KBr}, \mathrm{cm}^{-1}\right)$ : $3010(\mathrm{ArH}), 2995$ $\left(-\mathrm{CH}_{2} \mathrm{CH}_{3}\right), 2223(-\mathrm{CN}), 1714(\mathrm{C}=\mathrm{O}), 1602(\mathrm{C}=\mathrm{C}), 1270(\mathrm{C}-\mathrm{O})$, 844 (ArH).

\section{Conflicts of interest}

There are no conflicts to declare.

\section{Acknowledgements}

We are grateful for the financial support for this work from Natural Science Foundation of Shanxi Province (No. 201601D102015), the Higher School Science \& Technology Development Project of Shanxi Province Education Department (No. [2017]171), the Key Research and Development Project of Xinzhou City ([2017]0302) and the College Students Innovation Project of Xinzhou Teachers University ([2016]32). 


\section{Notes and references}

1 L. F. Tietze, Chem. Rev., 1996, 96, 115.

2 F. Freeman, Chem. Rev., 1980, 80, 329.

3 G. A. Kraus and M. E. Krolski, J. Org. Chem., 1986, 51, 3347.

4 L. F. Tietze and N. Rackelmann, Pure Appl. Chem., 2004, 76, 1967.

5 F. Liang, Y.-J. Pu, T. Kurata, J. Kido and H. Nishide, Polymer, 2005, 46, 3767.

6 (a) F.-G. Xi, H. Liu, N.-N. Yang and E.-Q. Gao, Inorg. Chem., 2016, 55, 4701; (b) P. V. Dau and S. M. Cohen, Inorg. Chem., 2015, 54, 3134; (c) M. Zhao, K. Deng, L. He, Y. Liu, G. Li, H. Zhao and Z. Tang, J. Am. Chem. Soc., 2014, 136, 1738.

7 G. Li, J. Xiao and W. Zhang, Green Chem., 2012, 14, 2234.

8 S. K. Panja, N. Dwivedi and S. Saha, RSC Adv., 2015, 5, 65526. 9 H. Wang, C. Wang, Y. Yang, M. Zhao and Y. Wang, Catal. Sci. Technol., 2017, 7, 405.

10 T. Murase, Y. Nishijima and M. Fujita, J. Am. Chem. Soc., 2012, 134, 162.

11 E. M. Schneider, M. Zeltner, N. Kränzlin, R. N. Grass and W. J. Stark, Chem. Commun., 2015, 51, 10695.

12 T. C. Keller, S. Isabettini, D. Verboekend, E. G. Rodrigues and J. Pérez-Ramírez, Chem. Sci., 2014, 5, 677.

13 X. Garrabou, B. I. M. Wicky and D. Hilvert, J. Am. Chem. Soc., 2016, 138, 6972.

14 (a) S. Kumar Dey, N. de Sousa Amadeu and C. Janiak, Chem. Commun., 2016, 52, 7834; (b) A. Karmakar, A. Paul, K. T. Mahmudov, M. F. C. G. da Silva and A. J. L. Pombeiro, New J. Chem., 2016, 40, 1535.

15 P. Ramesh, B. Shalini and N. W. Fadnavis, RSC Adv., 2014, 4, 7368.

16 A. Ying, F. Qiu, C. Wu, H. Hu and J. Yang, $R S C A d v ., 2014,4$, 33175 .

17 F. Zhang, H. Jiang, X. Li, X. Wu and H. Li, ACS Catal., 2014, 4, 394.

18 (a) N. Mase and T. Horibe, Org. Lett., 2013, 15(8), 1854; (b) W. Li, S. N. Fedosov, T. Tan, X. Xu and Z. Guo, ACS Catal., 2014, 4, 3294.

19 (a) L. Bai, J.-X. Wang and Y. Zhang, Green Chem., 2003, 5, 615; (b) S.-H. Zhao, Q.-J. Zhang, X.-E. Duan and L. H. Feng, Synth. Commun., 2011, 41, 3289; (c) S. Zhao, X. Wang and L. Zhang, RSC Adv., 2013, 3, 11691; (d) G. Chatel and D. R. MacFarlane, Chem. Soc. Rev., 2014, 43, 8132.

20 (a) S.-H. Zhao, H.-R. Zhang, L.-H. Feng and Z.-B. Chen, J. Mol. Catal. A: Chem., 2006, 258, 251; (b) M. G. Freire,
A. F. M. Cláudio, J. M. M. Araújo, J. A. P. Coutinho, I. M. Marrucho, J. N. C. Lopesac and L. P. N. Rebelo, Chem. Soc. Rev., 2012, 41, 4966.

21 (a) Y. Zhu, L. Zhang and S. Luo, J. Am. Chem. Soc., 2014, 136, 14642; (b) N. Fu, L. Zhang and S. Luo, Org. Lett., 2015, 17(2), 382.

22 D. Elhamifar, S. Kazempoor and B. Karim, Catal. Sci. Technol., 2016, 6, 4318.

23 (a) Z. N. Siddiqui and K. Khan, ACS Sustainable Chem. Eng., 2014, 2, 1187; (b) S. Zhao, X. Wang and L. Zhang, RSC Adv., 2013, 3, 11691.

24 (a) D.-Z. Xu, Y. Liu, S. Shi and Y. Wang, Green Chem., 2010, 12, 514; (b) C. Yang, W.-Q. Su and D.-Z. Xu, RSC Adv., 2016, 6, 99656.

25 R. C. M. A. Sobrinho, P. M. de Oliveira, C. R. M. D'Oca, D. Russowsky and M. G. M. D'Oca, RSC Adv., 2017, 7, 3214.

26 (a) J. S. Wilkes and M. J. Zaworotko, Chem. Commun., 1992, 965; (b) J. D. Holbrey, M. B. Turner, W. M. Reichert and R. D. Rogers, Green Chem., 2003, 5, 731.

27 (a) F. Bellina, A. Bertoli, B. Melai, F. Scalesse, F. Signoric and C. Chiappe, Green Chem., 2009, 11, 622; (b) M. Deetlefs and K. R. Seddon, Green Chem., 2003, 5, 181.

28 (a) J. Li, X. Wang and Y. Zhang, Tetrahedron Lett., 2005, 46, 5233; (b) J. S. Yadav, B. V. S. Reddy and G. Baishya, J. Org. Chem., 2003, 68, 7098; (c) C.-J. Li and L. Chen, Chem. Soc. Rev., 2006, 35, 68.

29 (a) G. S. Owens and M. M. Abu-Omar, J. Mol. Catal. A: Chem., 2002, 187, 215; (b) F. Bellina, C. Chiappe and M. Lessl, Green Chem., 2012, 14, 148.

30 A. Song, X. Wang and K. S. Lam, Tetrahedron Lett., 2003, 44, 1755.

31 G. Li, J. Xiao and W. Zhang, Green Chem., 2011, 13, 1828.

32 F. D. Popp, J. Org. Chem., 1960, 25, 646.

33 H. Yasuda and H. Midorikawa, Bull. Chem. Soc. Jpn., 1966, 39, 1754.

34 C. Yue, A. Mao, Y. Wei and M. Lue, Catal. Commun., 2008, 9, 1571.

35 A. Ying, L. Wang, L. Wang, X. Chen and W. Ye, J. Chem. Res., 2010, 34, 30.

36 D. T. Mowry, J. Am. Chem. Soc., 1943, 65, 992.

37 J. Zhang, T. Jiang, B. Han, A. Zhu and X. Ma, Synth. Commun., 2006, 36, 3305.

38 S. Zhao, M. He, Z. Guo, N. Zhou and L. Zhang, RSC Adv., 2015, 5, 32839. 